УДК 616.718.4+616.718.5/.6]-001.5:614.86](045)

DOI: http://dx.doi.org/10.15674/0030-59872020233-39

\title{
Structure of long bone fractures of lower limbs at a car injury
}

\section{K. Sokol}

Kharkiv National Medical University. Ukraine

The most traumatized body region in road traffic accidents is the lower extremities, however, the structure of fractures has not been adequately studied. Objective: to study the structure of long bones fractures of the lower extremities in various nonlethal car injuries. Material and methods. The research material was 116 reports of primary forensic medical examinations of victims with fractures of the femur and/or shin bones resulting from a car injury. When studying the frequency of damage to various areas of the body and the frequency of fractures of long bones of the lower extremities, it was taken into account that 28 victims with polytrauma had multiple injuries, and thus 116 patients revealed 232 injuries of various areas of the body and 138 fractures of long bones of the lower legs. Research methods - retrospective analysis, descriptive statistics. Results. The main contingent of those injuries in the car accident was car drivers (8.5\%) and pedestrians (47.3\%) aged 31-50 years. In the general group, the shin (37.9\%), thigh (21.6\%), head $(13.8 \%)$ were most injured areas, in the group of car drivers neck, thigh, chest, shin, in the group of passengers - head, shin and thigh; pedestrians - shin, thigh, head. Due to the predominance of anterior (41.4\%) and anterolateral collisions of a moving car in the group as a whole, in cases of the of pedestrians injuries as well as in cases of in-cabin injuries, the presence of bumper fractures of the lower leg bones, as well as fractures of the femur of various localization, was observed. Conclusions. According to the initial forensic medical examination, a collision of a moving car with a pedestrian (78.4\%) and a collision of moving vehicles (21.6\%) were observed in the structure of non-lethal car accidents. In this case, diaphyseal fractures of the femur (29.8\%) and the shin bones $(47.1 \%)$ in the general group and in the group of pedestrians (20.4 and $40.7 \%$, respectively) predominated. Fractures of the femur of various localization were most often detected also in the in-cabin injuries $150.0 \%$ of the total number of fractures in drivers and passengers). Key words: road traffic injury, femoral fractures, fractures of shin bones.

Key words: road traffic injury, femoral fractures, fractures of shin bones
Найбільш вразливою зоною в разі дорожньо-транспортноі пригоди (ДТП) є нижні кінцівки, проте структура переломів їхніх довгих кісток досліджена недостатньо. Мета: вивчити структуру переломів довгих кісток нижніх кінцівок у різних учасників нелетальної автомобільної травми. Методи: проаналізовано 116 актів первинних судово-медичних експертиз постраждалих із переломами стегновоі кістки та/або кісток гомілки, отриманих унаслідок ДТП. Через те, щяо у 28 постраждалих із політравмою були множинні ушкодження, у 116 осіб виявлено 232 ураження різних ділянок тіла та 138 переломів довгих кісток нижніх кінцівок. Проведено ретроспективний аналіз, використано методи описової статистики. Результати: основний контингент постраждалих унаслідок ДТП - водії легкових автомобілів (8,5\%) і пішоходи (47,3\%) у вічі 31-50 років. Загалом найчастіме травмовано гомілку (37,9\%), стегно (21,6\%), голову (13,8\%); у групі водіїв авто - шию, стегно, грудну клітку, гомілку; у групі пасажирів - голову, гомілку та стегно; у пішоходів - гомілку, стегно, голову. У результаті переважання переднього (41,4\%) і передньобокового (32,8\%) зіткнень рухомого автомобіля загалом по групі, у разі пішоходної, а також внутрішньосалонної травм, була характерною наявність бамперних переломів кісток гомілки, стегнової кістки різної локалізації. Висновки: у структурі нелетальної автотравми за даними первинної судово-медичної експертизи спостерігали зіткнення рухомого автомобіля з пішоходом (78,4\%) або рухомих транспортних засобів (21,6\%). При иьому переважали діафізарні переломи стегнової кістки (29,8\%) і кісток гомілки (47,1\%) загалом у групі та серед пішоходів (20,4 і 40,7\% відповідно). Переломи стегнової кістки різної локалізації найчастіше виявлені в разі внутрішньосалонної травми (50,0\% від загальної кількості переломів у водїв $і$ пасажсиів). Ключові слова: дорожньо-транспортна травма, переломи стегнової кістки, переломи кісток гомілки. 


\section{Introduction}

Over the years, road traffic accidents (RTA) remain a constant endemic phenomenon and a heavy economic and medical-social burden for many countries of the world. According to the report of the World Health Organization (WHO) in 2018, 1.35 million lethal (fatal) RTA were recorded in 2016, which resulted in road traffic injury taking the $8^{\text {th }}$ place among causes of death in the general population and the 1 place in children and young people aged 5 to 29 years [1]. In high-income countries, in 2016, deaths from road accidents between the ages of 15 and 49 reached $9.5 \%$ (9.0-9.9), amounting to approximately 255 million DALYs (Disability- adjusted life year) [2]. Given the potentially lost years of life, the socio-economic losses of society due to fatal accidents exceed similar indicators for malignant diseases, heart diseases and cerebrovascular diseases [3].

In Ukraine, 4687 fatal RTA (76\% of men, $24 \%$ of women) were recorded in 2016, according to WHO, their number was 6089 ; per 100000 of the population - 13.7 deaths from road traffic injuries, which exceeds the average in Europe (10.4 per 100000 of the population) and the USA (12.4 per 100000 of the population) [1]. In Ukraine, mortality of pedestrians $(42 \%)$, passengers $(18 \%)$ and drivers $(16 \%)$ of 4-wheeled vehicles occurs the most in RTA. A different structure of fatal RTA is observed in highly developed countries. In the United Kingdom and the USA, the percentage of mortality among pedestrians is 24 and $15 \%$, respectively; for 4 -wheeled vehicles: among passengers 14 and $17 \%$, respectively; among drivers - 33 and $47 \%$, respectively [1].

Epidemiology and risk factors for fatal RTA are studied comprehensively at both the national level and the WHO. At the same time, the structure of nonlethal road traffic injuries is less known. It is been reported that, regardless of the type of RTA (collision of vehicles, collision of a vehicle and a pedestrian, collision of a vehicle with a fixed obstacle) and its participants (pedestrian, driver and/or passenger of a car/motorcycle/scooter/bicycle), the lower limbs are most often injured [4-6]. However, the structure of lower limb injuries in various types of injured in non-fatal RTA has not been sufficiently studied.

Objective: to study the structure of lower limb fractures in various participants in non-lethal car injuries.

\section{Material and methods}

The research material - 116 reports of primary forensic medical examinations of victims with fractures of the femur and/or lower leg bones resulting from a non-lethal car accident. In all cases, an expert assessment of the nature of traumatic injuries was carried out at the Kharkov Regional Bureau of Forensic Medical Examination (KRBFME) for a period not exceeding month after an injury. Reports of primary forensic medical examinations were selected by random sampling for the period February-June 2018.

Inclusion criteria - isolated fractures of the femur or lower leg bones; non-lethal polytrauma with fractures of long bones of the lower extremities as a leading injury received by drivers, passengers of vehicles, pedestrians as a result of a collision with a car.

Exclusion criteria - non-lethal polytrauma, in which fractures of the long bones of the lower extremities were a concomitant injury; car accident in which the forensic medical examination was carried out in terms exceeding month; fractures of long bones of the lower extremities obtained as a result of other mechanisms (except for car injury), fatal car injury.

All victims of road accidents were selected in group 1 «car injury» $(\mathrm{n}=116,100 \%)$; there were also selected: for group 2 - drivers of a four-wheeled (passenger car) vehicle $(\mathrm{n}=11,9.5 \%)$; for group 3 drivers of 2-wheeled (bicycle, scooter) vehicles $(n=4$, $3.4 \%$ ); for group 4 - passengers of the front seat of 4-wheeled vehicles $(n=6,5.2 \%)$; for group 5 rear-seat passengers of 4 -wheeled vehicles $(n=1$, $0.9 \%$ ); for group $6-$ passengers of 2 -wheeled (bicycle, motorcycle) vehicles $(\mathrm{n}=3,2.6 \%)$; for group 7 - pedestrians $(n=91,78.4 \%)$.

When classifying injuries, resulted from car injury, into isolated fractures of long bones of the lower extremities, multiple and combined injuries, we conditionally did not take into account injuries of the integumentary system (abrasions, superficial bruised wounds, subcutaneous hematomas), qualified as light bodily injuries (according to «Rules of forensic determination of the severity of injuries», approved by Ministry of Health of Ukraine Order No.6 dated 01.17.1995). Also, mild and moderate brain concussion, superficial neck injuries, bone fractures and dislocations of the joints of the upper extremities, bruises of the chest and abdomen, non-penetrating fractures of the ribs, fractures of the pelvic bones without damaging internal organs were taken into account.

In the study of the frequency of damage to various areas of the body and the frequency of fractures to long bones of the lower extremities, it was taken into account that, among 19 patients with multiple injuries of the locomotor system, in 2 patients injuries of the lower extremities in combination with dislocation of the joint of the upper limb were defined; in 4 - in combination with damage to the upper limb; 
in $2-$ a fracture of the pelvic bones and 2 fractures of the bones in one segment of the lower limb; in 2 - a fracture of the pelvic bones and damage to 2 segments of the lower extremities; 1 - bone fractures of 3 segments of the lower extremities; in 8 - bone fractures of 2 segments of the lower extremities. In the group of victims with combined trauma in the $1^{\text {st }}$ case, damage was defined in 2 segments of the upper limb and 3 segments of the lower extremities; in 4 - fractures of the pelvic bones and 2 segments of the lower extremities; in $4-$ damage to 2 segments of the lower extremities. Thus, in 116 victims of a car accident, 232 injuries of various areas of the body and 138 fractures of long bones of the lower extremities were recorded.

Research methods - retrospective analysis, descriptive statistics.

\section{Results and discussion}

The average age of victims of a car accident was (42.8 \pm 24.3$)$ years (10-81 years), a slight predominance of men was observed (54.3\%). The main contingent of victims was car drivers $(8.5 \%)$ and pedestrians $(47.3 \%)$ in the age group of $31-50$ years old, and almost one third $(24.2 \%)$ of pedestrians were older 51 years. It should be noted that, in the general group 1, «the number of men: the number of women» ratio did not exceed $1.2: 1$, in the group of car drivers it reached $4.5: 1$, and in the group of pedestrians it was $0.98: 1$ (table 1$)$.

Car accident was the result of 2 types of RTA: collision of a moving car with a pedestrian $(78.4 \%)$ and collision of moving vehicles (21.6\%). RTA prevailed in the city (92.2\%); pedestrian collisions in other settlements occurred in $6.0 \%$ of cases, collision of moving vehicles on the roads - in $1.7 \%$.
According to the nature of the injuries received, as expected, combined damage prevailed $(71.5 \%)$. Isolated fractures of long bones of the lower extremities and multiple injuries of locomotor system were observed much less frequently with approximately the same frequency: $12.1 \%$ and $16.4 \%$, respectively. For pedestrians, a similar distribution of the frequency of isolated and multiple damage to the locomotor system was noted. A slightly different picture was observed with in-cabin injury. If we take for $100 \%$ the number of victims in the passenger compartment $(n=18)$, we can see the prevalence of multiple injuries over isolated fractures of long bones of the lower extremities: $33 \%$ and $17 \%$, respectively (table 2 ).

The most frequently injured areas of the body in the victims in car accidents were: shin (37.9\%), thigh $(21.6 \%)$ and the head $(12.5 \%)$. The least injured were the forearm and the foot $(1.3 \%$ each), the wrist $(1.7 \%)$ (table 3). The frequency of injuries of various areas of the body in various groups of participants in an accident was as follows: in case of in-cabin injury $(\mathrm{n}=18,100 \%$ ), thigh injuries (for drivers - $38.9 \%$; for passengers - $33.3 \%$ ), shin injuries (33.3 and $38.9 \%$, respectively), head injuries (38.9 and $27.8 \%$, respectively) and neck superficial injuries (27.8\% each) were characteristic. In addition, car drivers were distinguished by injuries to the chest $(33.3 \%)$ and abdomen (22.2\%). In pedestrians $(\mathrm{n}=91,100 \%)$, the shin was mostly damaged $(73.6 \%)$; injuries of the thigh area were noted in $35.2 \%$ of cases, heads in $14.3 \%$ and pelvis in $12.1 \%$. Injuries of the upper extremities, chest and abdomen were noted less frequently: $8.8,4.4$ and $6.6 \%$, respectively. Thus, among injuries of various areas of the body, during an car injury, fractures of long bones of the lower extremities took a leading place both in general group

Table 1

Distribution by gender and age of injured in car accidents

\begin{tabular}{|l|c|c|c|c|c|c|c|}
\hline \multirow{2}{*}{ The characteristic } & \multicolumn{7}{|c|}{ The groupe of victims } \\
\cline { 2 - 7 } & $\begin{array}{c}1 \\
\mathrm{n}=116 ; 100 \%\end{array}$ & $\begin{array}{c}2 \\
\mathrm{n}=11 ; 9.5 \%\end{array}$ & $\begin{array}{c}3 \\
\mathrm{n}=4 ; 3.4 \%\end{array}$ & $\begin{array}{c}4 \\
\mathrm{n}=6 ; 5.2 \%\end{array}$ & $\begin{array}{c}5 \\
\mathrm{n}=1 ; 0.9 \%\end{array}$ & $\begin{array}{c}6 \\
\mathrm{n}=3 ; 2.6 \%\end{array}$ & $\begin{array}{c}7 \\
\mathrm{n}=91 ; 78.4 \%\end{array}$ \\
\hline Gender: & $63 ; 54.3 \%$ & $9 ; 7.8 \%$ & $3 ; 2.5 \%$ & $4 ; 3.4 \%$ & - & $2 ; 1.7 \%$ & $45 ; 38.8 \%$ \\
\hline male & $53 ; 45.7 \%$ & $2 ; 1.7 \%$ & $1 ; 0.9 \%$ & $2 ; 1.7 \%$ & $1 ; 0.9 \%$ & $1 ; 0.9 \%$ & $46 ; 39.7 \%$ \\
\hline female & \multicolumn{7}{|l|}{} \\
\hline Age (years): \\
\hline $10-20$ & $4 ; 3,4 \%$ & - & - & - & $1 ; 0.9 \%$ & $1 ; 0.9 \%$ & $2 ; 1.7 \%$ \\
\hline $21-30$ & $12 ; 10,3 \%$ & - & $3 ; 2,5 \%$ & $1 ; 0,9 \%$ & - & $2 ; 1.7 \%$ & $6 ; 5.2 \%$ \\
\hline $31-40$ & $43 ; 37,2 \%$ & $7 ; 6,0 \%$ & $1 ; 0,9 \%$ & $4 ; 3,4 \%$ & - & - & $31 ; 26.6 \%$ \\
\hline $41-50$ & $28 ; 24,1 \%$ & $3 ; 2,5 \%$ & - & $1 ; 0,9 \%$ & - & - & $24 ; 20.7 \%$ \\
\hline $51-60$ & $15 ; 12,9 \%$ & $1 ; 0,9 \%$ & - & - & - & - & $14 ; 12.1 \%$ \\
\hline$>61$ & $14 ; 12,1 \%$ & - & - & - & - & - & $14 ; 12.1 \%$ \\
\hline
\end{tabular}


$1(59.5 \%)$ and in the groups of drivers, car passengers (72.2\% each) and especially pedestrians (108.8\%), where damage was observed in two segments (thigh and shin or both shins) (table 3).

In the structure of fractures of long bones of the lower extremities in the general group 1, shaft fractures of the femur $(29.8 \%)$ and shin bones (47.1\%) prevailed. Those fractures were a leading injury in the group of pedestrians (20.4 and $40.7 \%$, respectively). In addition, femur fractures were «leaders» in case of in-cabin injury: for drivers and passengers of cars $(\mathrm{n}=18,100 \%)$, their total percentage was $50.0 \%$ (table 4).

This nature of the damage corresponds to the mechanism of car injury, in which the anterior (41.4\%) and anterolateral $(32.8 \%)$ collisions of a moving car with a pedestrian prevailed. As a result of the collision, the frontal parts of the car collide with the lower limbs of the pedestrian with the formation of bum- per fractures of the shin bones. Due to the impact below the level of the center of mass of a person, a torque arises, as a result of which the head, upper limbs and upper half of the pedestrian's body deviate towards the car, and the lower limbs are shifted up and along the vehicle. Often, in this phase, a second blow of the car's hood on the pedestrian's hips occurs $[7,8]$. Fractures of the diaphysis of the femur and tibia, injuries of the knee joint and the distal tibia also correspond to injuries during in-cabin injury [9]. Fracture of the acetabulum with a central dislocation of the femur is a typical injury to a driver of a car in a frontal collision [10].

The structure of RTA to a certain extent depends on the economic, social, cultural characteristics of the studied region. So, automobile injuries lead in the developed countries of Europe and North America, and motorcycle and bicycle injuries - in the countries of Africa and Southeast Asia [11, 12].

The nature of damage to the musculoskeletal system in various injured in car accidents

\begin{tabular}{|l|c|c|c|c|c|c|c|c|}
\hline \multirow{2}{*}{ Parameters } & \multicolumn{9}{|c|}{ Nature of car injury (n=116; $100 \%)$} \\
\cline { 2 - 10 } & $\begin{array}{c}\text { isolated fractures } \\
\text { of femur/ lower leg bones }\end{array}$ & \multicolumn{2}{|c|}{ multiple injury } & \multicolumn{3}{|c|}{ polytrauma } & \multicolumn{2}{c|}{ total } \\
\cline { 2 - 11 } & abs. & $\%$ & abs. & $\%$ & abs. & $\%$ & abs. & $\%$ \\
\hline Car injury: & 14 & 12.1 & 19 & 16.4 & 83 & 71.5 & 116 & 100.0 \\
\hline - drivers of 4-wheeled vehicles; & 1 & 0.9 & 3 & 2.6 & 7 & 6.0 & 11 & 9.5 \\
\hline - drivers of 2-wheeled vehicles; & 1 & 0.9 & 2 & 1.7 & 1 & 0.9 & 4 & 3.4 \\
\hline - front-seat passengers of 4-wheeled vehicles; & 2 & 1.7 & 2 & 1.7 & 2 & 1.7 & 6 & 5.2 \\
\hline - rear-seat passengers of 4-wheeled vehicles; & - & - & 1 & 0.9 & - & - & 1 & 0.9 \\
\hline - passengers of 2-wheeled vehicles; & - & - & 1 & 0.9 & 2 & 1.7 & 3 & 2.6 \\
\hline - pedestrians & 10 & 8.6 & 10 & 8.6 & 71 & 61.2 & 91 & 78.4 \\
\hline
\end{tabular}

The structure of damage to various areas of the body in victims in a car accident

Table 3

\begin{tabular}{|l|c|c|c|c|c|c|c|}
\hline \multirow{2}{*}{ Injured segment } & \multicolumn{7}{|c|}{ The group of victims } \\
\cline { 2 - 8 } & $\begin{array}{c}1 \\
(\mathrm{n}=116)\end{array}$ & $\begin{array}{c}2 \\
(\mathrm{n}=11)\end{array}$ & $\begin{array}{c}3 \\
(\mathrm{n}=4)\end{array}$ & $\begin{array}{c}4 \\
(\mathrm{n}=6)\end{array}$ & $\begin{array}{c}5 \\
(\mathrm{n}=1)\end{array}$ & $\begin{array}{c}6 \\
(\mathrm{n}=3)\end{array}$ & $\begin{array}{c}7 \\
(\mathrm{n}=91)\end{array}$ \\
\hline Head & $29 ; 12.5 \%$ & $7 ; 3.0 \%$ & $1 ; 0.4 \%$ & $4 ; 1.7 \%$ & $1 ; 0.4 \%$ & $1 ; 0.4 \%$ & $15 ; 6.5 \%$ \\
\hline Neck & $1 ; 4.7 \%$ & $5 ; 2.2 \%$ & $1 ; 0.4 \%$ & $4 ; 1.7 \%$ & - & - & $1 ; 0.4 \%$ \\
\hline Shoulder & $8 ; 3.4 \%$ & - & $1 ; 0.4 \%$ & $1 ; 0.4 \%$ & - & - & $6 ; 2.6 \%$ \\
\hline Forearm & $3 ; 1.3 \%$ & - & $1 ; 0.4 \%$ & - & - & - & $2 ; 0.9 \%$ \\
\hline Wrist & $4 ; 1.7 \%$ & $1 ; 0.4 \%$ & $1 ; 0.4 \%$ & - & - & - & $2 ; 0.9 \%$ \\
\hline Chest & $12 ; 5.2 \%$ & $6 ; 2.6 \%$ & $1 ; 0.4 \%$ & $1 ; 0.4 \%$ & - & - & $4 ; 1.7 \%$ \\
\hline Abdomen & $11 ; 4.7 \%$ & $4 ; 1.7 \%$ & - & $1 ; 0.4 \%$ & - & - & $6 ; 2.6 \%$ \\
\hline Pelvis & $13 ; 5.7 \%$ & $2 ; 0.9 \%$ & - & - & - & - & $11 ; 4.7 \%$ \\
\hline Thigh & $50 ; 21.6 \%$ & $7 ; 3.0 \%$ & $4 ; 1.7 \%$ & $5 ; 2.2 \%$ & $1 ; 0.4 \%$ & $1 ; 0.4 \%$ & $32 ; 13.8 \%$ \\
\hline Shin & $88 ; 37.9 \%$ & $6 ; 2.6 \%$ & $4 ; 1.7 \%$ & $6 ; 2.6 \%$ & $1 ; 0.4 \%$ & $4 ; 1.7 \%$ & $67 ; 28.9 \%$ \\
\hline Foot & $3 ; 1.3 \%$ & - & $1 ; 0.4 \%$ & - & - & - & $2 ; 0.9 \%$ \\
\hline Total & $232 ; 100.0 \%$ & $38 ; 16.4 \%$ & $15 ; 6.5 \%$ & $22 ; 9.5 \%$ & $3 ; 1.2 \%$ & $6 ; 2.6 \%$ & $148 ; 63.8 \%$ \\
\hline
\end{tabular}


The structure of fractures of long bones of the lower extremities in various injured in car accidents

\begin{tabular}{|c|c|c|c|c|c|c|c|}
\hline \multirow[t]{2}{*}{ The nature of the lower limb injury } & \multicolumn{7}{|c|}{ The group of victims } \\
\hline & $\begin{array}{c}1 \\
(\mathrm{n}=116)\end{array}$ & $\begin{array}{c}2 \\
(\mathrm{n}=11)\end{array}$ & $\left(\begin{array}{c}3 \\
=4\end{array}\right)$ & $\begin{array}{c}4 \\
(n=6)\end{array}$ & $\begin{array}{c}5 \\
(\mathrm{n}=1)\end{array}$ & $\begin{array}{c}6 \\
(\mathrm{n}=3)\end{array}$ & $\begin{array}{c}7 \\
(\mathrm{n}=91)\end{array}$ \\
\hline $\begin{array}{l}\text { Fracture of the acetabulum } \\
\text { with a central dislocation of the thigh }\end{array}$ & $2 ; 1.4 \%$ & $2 ; 1.4 \%$ & - & - & - & - & - \\
\hline Medial femoral neck fracture & $2 ; 1.4 \%$ & - & - & - & - & - & $2 ; 1.4 \%$ \\
\hline Transtrochanteric fracture of the femur & $1 ; 0.7 \%$ & - & - & - & - & - & $1 ; 0.7 \%$ \\
\hline Shaft fracture of the femur & $41 ; 29.8 \%$ & $4 ; 2.9 \%$ & - & $4 ; 2.9 \%$ & $1 ; 0.7 \%$ & $1 ; 0.7 \%$ & - \\
\hline Fracture of the distal femur epimetaphysis & $4 ; 2.9 \%$ & $1 ; 0.7 \%$ & $1 ; 0.7 \%$ & $1 ; 0.7 \%$ & - & - & $1 ; 0.7 \%$ \\
\hline Fracture of the proximal tibia epimetaphysis & $11 ; 8.0 \%$ & $1 ; 0.7 \%$ & $1 ; 0.7 \%$ & $2 ; 1.4 \%$ & - & $1 ; 0.7 \%$ & $6 ; 4.3 \%$ \\
\hline Diaphyseal fracture of the lower leg bones & $65 ; 47.1 \%$ & $1 ; 0.7 \%$ & $2 ; 1.4 \%$ & $3 ; 2.3 \%$ & $1 ; 0.7 \%$ & $2 ; 1.4 \%$ & $56 ; 40.7 \%$ \\
\hline Double diaphyseal fracture of the lower leg bones & $1 ; 0.7 \%$ & - & - & - & - & - & $1 ; 0.7 \%$ \\
\hline Fracture of the inner / outer ankle & $7 ; 5.1 \%$ & $3 ; 2.3 \%$ & $1 ; 0.7 \%$ & $1 ; 0.7 \%$ & - & - & $2 ; 1.4 \%$ \\
\hline Fracture of both ankles & $4 ; 2.9 \%$ & $1 ; 0.7 \%$ & - & - & - & $1 ; 0,7 \%$ & $2 ; 1,4 \%$ \\
\hline Total & $138 ; 100.0 \%$ & $13 ; 9.4 \%$ & $8 ; 5.8 \%$ & $11 ; 8.0 \%$ & $2 ; 1.4 \%$ & $5 ; 3.6 \%$ & $99 ; 71.7 \%$ \\
\hline
\end{tabular}

In this regard, the victims of non-lethal car injuries are active (drivers) and passive (passengers, pedestrians) road users of almost all age periods with a predominance of people of working age and some prevalence of men [13]. Road traffic injury involving 2 -wheeled vehicles is seasonal (with an increase in the number of RTA in the spring and summer [14]), its victims are mostly young males (20-39 years old), in which, in addition to the lower extremities, injuries of the head, shoulder girdle and upper limbs are recorded with high frequency $[15,16]$. The frequency of non-fatal and, especially, fatal motorcycle injuries, regardless of the region (developed or developing countries), is significantly higher in people with low socio-economic status (unemployed, illiterate, literate at the initial level, low-skilled workers) [17-19].

Fatal outcomes at the age of 65-74 years are uncharacteristic for RTA, although the level of hospitalization of older victims increases $[6,20]$. Among the risk factors affecting the gender distribution of RTA victims, it is worth noting the risky behavior of male vehicle drivers with less frequent use of seat belts and frequent use of a mobile phone compared to women [21]. Pregnant women also fall into the same risk group and avoid using seat belts to prevent fetal damage [22]. In RTA outside the city, men participated 4 times more often than in urban accidents [23].

Road traffic injuries are the most common cause of fractures in human bones [24, 25], and fractures of long bones of the lower extremities, regardless of the circumstances of RTA, are the most frequently damaged areas of the human body [2, 5, 6, 12, 26]. Isolated fractures of the femur or shin bones are rare when vehicles collide with each other or hit a pedestrian at a low $(30-40 \mathrm{~km} / \mathrm{h})$ speed. With an increase in the speed of vehicles involved in RTA, the severity of the injury and the number of skeleton fractures increase accordingly. In non-lethal polytrauma, fractures of the femur and shin bones with fractures with the pelvic bones fractures, fractures of the long bones of the upper extremities are most often recorded [25-28]. Closed fractures of long bones of the lower extremities are more typical for drivers and passengers of automobiles [25], while a motorcycle injury is distinguished by the predominance of open multifragmented fractures of limb bones [27]. About $40 \%$ of victims with polytrauma and multiple bone fractures exceeded speed [25], moreover, at a car speed of $50 \mathrm{~km} / \mathrm{h}$, the risk of a fatal collision with a pedestrian is $26 \%$, at a speed of $58 \mathrm{~km} / \mathrm{h}-50$ and $82 \%$ - at $70 \mathrm{~km} / \mathrm{h}$ [28]. At the same time, a decrease in vehicle speed from $40 \mathrm{~km} / \mathrm{h}$ to $30 \mathrm{~km} / \mathrm{h}$ reduces the risk of collision with a pedestrian by $28 \%[29]$.

\section{Conclusions}

In the structure of non-lethal road traffic injury according to the initial forensic medical examination, the most common types of accidents were a collision of a moving car with a pedestrian (78.4\%) and a collision of moving vehicles (21.6\%).

According to the initial forensic medical examination, the main contingent of victims of car injuries was pedestrians, $47.3 \%$ of them were $31-50$ years old and $24.2 \%$ were older 51 years. In case of an internal cabin injury $(\mathrm{n}=18)$, car drivers $(\mathrm{n}=10)$ aged $31-50$ years prevailed. For pedestrians, the gender 
distribution was almost the same with the ratio of the number of men: the number of women was $0.98: 1$. Car drivers were dominantly men, in a ratio of $4.5: 1$.

In injured from car injuries combined damage prevailed $(71.5 \%)$; isolated fractures of long bones of the lower extremities and multiple injuries were observed with almost the same frequency in the general group (12.1 and $16.4 \%$, respectively) and in the group of pedestrians $(\mathrm{n}=91,11.6 \%$ each). On cases of in-cabin injuries, multiple injuries prevailed (17.0 and $33.0 \%$, respectively).

In the structure of fractures of long bones of the lower extremities, diaphyseal fractures of the femur $(29.8 \%)$ and shin bones $(47.1 \%)$ prevailed in the general group and in the group of pedestrians (20.4 and $40.7 \%$, respectively). Fractures of the femur of various localization were most often observed in the incabin injury $(50.0 \%$ of the total number of fractures in drivers and passengers).

Conflict of interest. The author declare the absence of conflict of interest.

\section{References}

1. Global status report on road safety 2018. Geneva: World Health Organization; 2018. Licence: CC BY- NC-SA 3.0 IGO. 403 p.

2. Hoogervorst $\mathrm{P}$. The burden of high-energy musculoskeletal trauma in high-income countries / P. Hoogervorst, D. W. Shearer, T. Miclau // World Journal of Surgery. — 2020. — Vol. 44. P. 1033-1038. - DOI: 10.1007/s00268-018-4742-3.

3. Stinner D. J. Surgical management of musculoskeletal trauma/ D. J. Stinner, D. Edwards // Surgical Clinics of North America. — 2017. — Vol. 97. — P. 1119-1131. — DOI: 10.1016/ j.suc.2017.06.005.

4. Road traffic collisions-case fatality rate, crash injury rate, and number of motor vehicles: time trends between a developed and developing country / S. S. Goonewardene, K. Baloch, K. Porter [et al]. // The American Surgeon. - 2010. - Vol. 76 (9). P. 977-981.

5. Mishra A. N. Pattern of injuries in road traffic accident in northern Indian population / A. N. Mishra, S. A. Qidwai, S. Mishra // International Journal of Orthopaedics Sciences. - 2017. — Vol. 3 (4m). - P. 917-919. — DOI: 10.22271/ ortho.2017.v3.i4m.124.

6. Azami-Aghdash S. Epidemiology of road traffic injuries among elderly people; a systematic review and meta-analysis / S. Azami-Aghdash, M. H. Aghaei, H. Sadeghi-Bazarghani // Bulletin of Emergency and Trauma. - 2018. - Vol. 6 (4). P. 279-291. — DOI: 10.29252/beat-060403.

7. Специфические телесные повреждения пешехода при автотравме («бампер-перелом») / В. Б. Барканов, В.В.Ермилов, В. В. Сивик [и др.] // Вестник ВолгГМУ. - 2018. - Т. 1, № 65. - C. 53-55. - DOI: 10.19163/1994-9480-2018-1(65)53-55.

8. Леонов С. В. Судебно-медицинская характеристика повреждений у пешехода при переднекраевом наезде автомобиля / С. В. Леонов, П. В. Пинчук // Судебно-медицинская экспертиза. - 2016. - № 4. - С. 21-24. DOI: 10.17116/sudmed201659421-24ю

9. Алпатов И. М. Дифференциальная диагностика травм водителя и пассажира переднего сиденья легкового автомобиля: Пособие для врачей, судебно-медицинских экс- пертов / И. М. Алпатов, Е. В. Никитина. - М., 2001. — 16 с.

10. Patterns of injury seen in road crash victims in a South African trauma centre / F Parkinson, S Kent, C Aldous C [et al] // South African Journal of Surgery. - 2013. - Vol. 51 (4). - P. 131-134. - DOI: 10.7196/SAJS.1627.

11. Rosén E. Literature review of pedestrian fatality risk as a function of car impact speed / E. Rosén, H. Stigson, U. Sander // Accident Analysis \& Prevention. - 2011. - Vol. 43 (1). P. 25-33. — DOI: 10.1016/j.aap.2010.04.003.

12. Comparative study of stewardship of road traffic injuries prevention with a focus on the role of health system; Three pioneer countries and three similar to Iran / S. Azami-Aghdash, H. Sadeghi-Bazarghani, R. Rezapour [et al.] // Bulletin of Emergency and Trauma. - 2019. - Vol. 7 (3). - P. 212-222. DOI: $10.29252 /$ beat- 070302 .

13. Anantharaman V. V. Epidemiology of road traffic accidents (RTA) reported at a Tertiary Care Hospital in Chennai / V. V. Anantharaman, M. Logaraj // National Journal of Research in Community Medicine. - 2015. - Vol. 4 (1). - P. 101-105.

14. Epidemiological patterns of road traffic crashes during the last two decades in Iran: a review of the literature from 1996 to 2014 / H. Sadeghi-Bazargani, H. Ayubi, S. Azami-Aghdash // Archives of Trauma Research. - 2016. - Vol. 5 (3). - Article ID: e32985. — DOI: 10.5812/atr.32985.

15. Ghorbanali M. Road traffic fatalities among pedestrians, bicyclists and motor vehicle occupants in Sirjan, Kerman, Iran / M. Ghorbanali // Chinese Journal of Traumatology (English Edition). - 2009. - Vol. 12, № 4. - P. 200-202.

16. Moafian G. An epidemiologic survey of road traffic accidents in Iran: analysis of driver-related factors / G. Moafian, M. R. Aghabeigi, A. Hoseinzadeh // Chinese Journal of Traumatology. - 2013. - Vol. 16 (3). - P. 140-144. — DOI: 10.3760/ cma.j.issn.1008-1275.2013.03.003.

17. Epidemiological characteristics of fatal traffic accidents in Fars province, Iran: a community-based survey / S. T. Heydari, A. Hoseinzadeh, A. Ghaffarpasand [et al.] // Public Health. - 2013. - Vol. 127 (8). — P. 704-709. — DOI: 10.1016/ j.puhe.2013.05.003.

18. Bjornskau T. Traffic safety among motorcyclists in Norway: A study of subgroups and risk factors / T. Bjornskau, T. O. Nevestad, J. Akhtar // Accident Analysis \& Prevention. - 2012. Vol. 49. - P. 50-57. — DOI: 10.1016/j.aap.2011.09.051.

19. Zambon F. Socioeconomic differences and motorcy- cle injuries: age at risk and injury severity among young drivers. A Swedish nationwide cohort study / F. Zambon, M. Hasselberg // Accident Analysis \& Prevention. - 2006. - Vol. 38 (6). P. 1183-1189. - DOI: 10.1016/j.aap.2006.05.005.

20. Impact of road traffic accidents on the elderly / H. Etehad, S. Yousefzadeh-Chabok, S. Davoudi-Kiakalaye [et al.] // Archives of Gerontology and Geriatrics. - 2015. - Vol. 61 (3). P. 489-493. — DOI: 10.1016/j.archger.2015.08.008.

21. Mohammadi G. Prevalence of seat belt and mobile phone use and road accident injuries amongst college students in Kerman, Iran / G. Mohammadi // Chinese Journal of Traumatology (English Edition). — 2011. — Vol. 14 (3). - P. 165-169. DOI: 10.3760/cma.j.issn.1008-1275.2011.03.008.

22. Seat belt use during pregnancy in Iran: attitudes and practices / M. Karbakhsh, Z. Ershadi, A. Khaji, F. Rahimi-Sharbaf // Chinese Journal of Traumatology (English Edition). — 2010. Vol. 13 (5). - C. 275-278. — DOI: 10.3760/cma.j.issn.10081275.2010.05.004.

23. Determinants of traffic injuries in drivers and motorcyclists involved in an accident / R. Majdzadeh, K. Khalagi, K. Naraghi [et al.] // Accident Analysis \& Prevention. - 2008. Vol. 40 (1). - P. 17-23. — DOI: 10.1016/j.aap.2007.03.019.

24. Adoga A. A. The epidemiology and type of injuries seen at the accident and emergency unit of a Nigerian referral centre / A. A. Adoga, K. N. Oziolo // Journal of Emergencies, 
Trauma, and Shock. — 2014. - Vol. 7 (2). - P. 77-82. DOI: $10.4103 / 0974-2700.130875$.

25. Sinha A. P. Study of Orthopedic Injuries Pattern by Road Traffic Accident Victims / A. P. Sinha // International Journal of Life-Sciences Scientific Research. - 2017. — Vol. 3 (2). P. 961-963. - DOI: 10.21276/ijlssr.2017.3.2.14.

26. Гур'єв С. О. Клініко-нозологічна структура пошкоджень довгих кісток у постраждалих внаслідок дорожно-транспортних пригод / С. О. Гур'єв, В. П. Свдошенко, С. П. Сацик // Травма. - 2015. - Т. 16, № 1. - С. 60-63.

27. Ravikanth R. Pattern and distribution of long bone fractures in victims of road traffic accidents in Bangalore city /
R. Ravikanth, P. S. Varghese // Indian Journal of Forensic Medicine \& Toxicology. - 2017. — Vol. 11 (1). - P. 229-232. DOI: 10.5958/0973-9130.2017.00047.0.

28. Kong C. Logistic regression analysis of pedestrian casualty risk in passenger vehicle collisions in China / C. Kong, J. Yang // Accident Analysis \& Prevention. - 2010. — Vol. 42 (4). P. 987-993. - DOI: 10.1016/j.aap.2009.11.006.

29. Effect of reducing the posted speed limit to $30 \mathrm{~km}$ per hour on pedestrian motor vehicle collisions in Toronto, Canada - a quasi experimental, pre-post study / L. Fridman, R. Ling, L. Rothman [et al.] // BMC Public Health. — 2020. — Vol. 20 (1). Article ID: 56. — DOI: 10.1186/s12889-019-8139-5.

\section{СТРУКТУРА ПЕРЕЛОМІВ ДОВГИХ КІСТОК НИЖНІХ КІНЦІВОК У РАЗІ АВТОТРАВМИ}

\section{В. К. Сокол}

Харківський національний медичний університет, Україна

$\checkmark$ Viacheslav Sokol, PhD: sokol_vk@ukr.net

\section{ДО УВАГИ СПЕЦІАЛІСТІВ}

ДУ «Інститут патології хребта та суглобів ім. проф. М. І. Ситенка НАМН Украӥни» проводить післядипломну підготовку фахівців на курсах інформації та стажування 3 актуальних питань ортопедії та травматології (ліцензія Міністерства освіти і науки України АЕ № 285527 від 27.11.2013)

Курси для середнього медичного персоналу:

Назва

Лікувальний масаж
Керівник

К. м. н. Стауде В. А. 